\title{
Characterization of a Ceramic Waste Form Encapsulating Radioactive Electrorefiner Salt
}

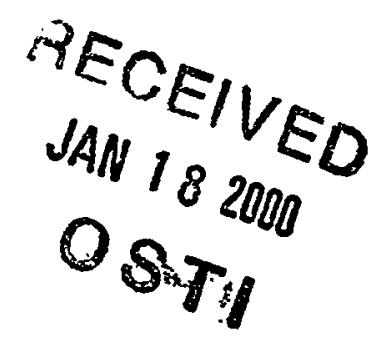

By:

T.L. Moschetti, W. Sinkler, T. DiSanto, M. Noy, A.R. Warren, D.G. Cummings, S,G. Johnson, K.M. Goff, K.J. Batemen, and S.M. Frank

Nuclear Technology Division

Argonne National Laboratory

P. O. Box 2528

Idaho Falls, ID 83403-2528

\begin{abstract}
The submitted manuscript has been created by the University of Chicago as Operator of Argonne National Laboratory ("Argonne") under Contract No. W-31-109-ENG-38 with the U.S. Department of Energy. The U.S. Government retains for itself, and others acting on its behalf, a paid-up, nonexclusive, irrevocable worldwide license in said article to reproduce, prepare derivative works, distribute copies to the public, and perform publicly and display publicly, by or on behalf of the Government.
\end{abstract}

Materials Research Society

Scientific Basis for Waste Management XXIII

Boston, MA

November 29 - December 3, 1999

*Work supported by the U. S. Department of Energy, Office of Nuclear Energy, Science and Technology, and the Office of Environmental Management, under contract W-31-109-Eng-38. 


\section{DISCLAIMER}

This report was prepared as an account of work sponsored by an agency of the United States Government. Neither the United States Government nor any agency thereof, nor any of their employees, make any warranty, express or implied, or assumes any legal liability or responsibility for the accuracy, completeness, or usefulness of any information, apparatus, product, or process disclosed, or represents that its use would not infringe privately owned rights. Reference herein to any specific commercial product, process, or service by trade name, trademark, manufacturer, or otherwise does not necessarily constitute or imply its endorsement, recommendation, or favoring by the United States Government or any agency thereof. The views and opinions of authors expressed herein do not necessarily state or reflect those of the United States Government or any agency thereof. 


\title{
DISCLAIMER
}

\begin{abstract}
Portions of this document may be illegible in electronic image products. Images are produced from the best available original document.
\end{abstract}




\title{
CHARACTERIZATION OF A CERAMIC WASTE FORM ENCAPSULATING RADIOACTIVE ELECTROREFINER SALT
}

\author{
T.L. Moschetti, W. Sinkler, T. DiSanto, M.H. Noy, A.R. Warren, D. Cummings, S.G. Johnson, \\ K.M. Goff, K.J. Bateman, and S.M. Frank \\ Argonne National Laboratory-West, P.O. Box 2528, Idaho Falls, ID 83403-2528
}

\begin{abstract}
Argonne National Laboratory has developed a ceramic waste form to immobilize radioactive waste salt produced during the electrometallurgical treatment of spent fuel. This study presents the first results from electron microscopy and durability testing of a ceramic waste form produced from that radioactive electrorefiner salt. The waste form consists of two primary phases: sodalite and glass. The sodalite phase appears to incorporate most of the alkali and alkaline earth fission products. Other fission products (rare earths and yttrium) tend to form a separate phase and are frequently associated with the actinides, which form mixed oxides. Seven-day leach test results are also presented.
\end{abstract}

\section{INTRODUCTION}

Argonne National Laboratory processes EBR-II spent fuel by an electrometallurgical treatment [1]. This treatment creates a radioactive salt waste stream containing transuranics and fission products. To immobilize the radioactive salt, a ceramic waste form has been developed [2-3]. The ceramic waste form (CWF) is produced by blending salt and zeolite $4 \mathrm{~A}$ at approximately $773 \mathrm{~K}$ resulting in a salt loading of about $10.5 \mathrm{wt} \%$. A composition of the electrorefiner salt incorporated into the waste form is given in Table I. The salt-loaded zeolite is then mixed with glass (in a weight ratio of 3:1) and hot isostatically pressed to obtain a consolidated, durable waste form. The maximum temperature and pressure within the hot isostatic press were $1123 \mathrm{~K}$ and $100 \mathrm{MPa}$. For the CWF, the uranium content is $0.5 \mathrm{wt} \%$ while the plutonium content is $0.02 \mathrm{wt} \%$ and neodymium, the dominant rare earth, is $0.05 \mathrm{wt} \%$.

Table I. Measured Composition of Electrorefiner Salt Incorporated in the Ceramic Waste Form.

\begin{tabular}{|ll|ll|}
\hline Element & Measured wt \% & Element & Measured wt \% \\
\hline $\mathrm{Li}$ & 5.87 & $\mathrm{La}$ & 0.21 \\
$\mathrm{Na}$ & 1.9 & $\mathrm{Ce}$ & 0.42 \\
$\mathrm{~K}$ & 21.3 & $\mathrm{Pr}$ & 0.21 \\
$\mathrm{Cs}$ & 0.66 & $\mathrm{Nd} \cdot$ & 0.70 \\
$\mathrm{Sr}$ & 0.15 & $\mathrm{Sm}$ & 0.21 \\
$\mathrm{Ba}$ & 0.25 & $\mathrm{~Np}$ & 0.0265 \\
$\mathrm{Y}$ & 0.12. & $\mathrm{U}^{\dagger}$ & 7.207 \\
$\mathrm{Fe}$ & 0.066 & $\mathrm{Pu}^{\dagger}$ & 0.291 \\
$\mathrm{Cl}$ & 57.63 & & \\
\hline
\end{tabular}

${ }^{\dagger}$ Isotopic compositions are approximately $60 \%{ }^{235} \mathrm{U}, 40 \%{ }^{238} \mathrm{U}$ and $9.9 \%{ }^{239} \mathrm{Pu}$, rest ${ }^{240} \mathrm{Pu}$ and ${ }^{238} \mathrm{Pu}$.

${ }^{\ddagger}$ Calculated assuming anionic composition is $100 \% \mathrm{Cl}^{-}$and standard chloride stoichiometries for all elements ( 3 chlorides for all rare earths and actinides). Analyses for iodide and bromide were not performed but are expected to be $350 \mu \mathrm{g} / \mathrm{g}$ and $45 \mu \mathrm{g} / \mathrm{g}$, respectively. 


\section{EXPERIMENTAL}

Both transmission electron microscopy (TEM) and scanning electron microscopy (SEM) were performed. The SEM was done with a Zeiss DSM 960A scanning electron microscope (Thornwood, NX). Energy dispersive and wavelength dispersive $\mathrm{x}$-ray spectroscopy (EDS/WDS) was done by interfacing the detectors and instrumentation of the microscope to an Oxford ISIS series $300 \mathrm{x}$-ray analysis system, software version 3.2, and the Oxford software Winspec, version 1.3 (Oxford, UK). The TEM was performed with a JEOL 2010 transmission electron microscope (Peabody, MA) operated at $200 \mathrm{kV}$, and equipped with a $\mathrm{LaB}_{6}$ filament and EDS detector. The instrument also has electron diffraction (ED) capabilities.

Product Consistency Tests (PCT-B) were performed according to ASTM C1285-94 [4]. The samples were first crushed and sieved to obtain particle sizes between 75-150 $\mu \mathrm{m}$. Then they were placed in de-mineralized water at $90^{\circ} \mathrm{C}$. The surface area-to-volume ratio (SA/V) was $2000 \mathrm{~m}^{-1}$ for the CWF. Upon completion of the PCT, chloride concentrations in the leachate were measured with an ion specific electrode and the $\mathrm{pH}$ with a $\mathrm{pH}$ meter. Other elemental concentrations in the leachate were determined with inductively coupled plasma-mass spectroscopy or -atomic emission spectroscopy. The normalized mass loss (NML) for various elements was calculated using

$$
N M L=\frac{C_{i} * V}{f_{i}^{*} S A}
$$

where $C_{i}$ is the concentration of the $i^{\text {th }}$ element in the leachate and $f_{i}$ is the mass fraction of the $i^{\text {th }}$ element in the unleached sample. Samples of the CWF were tested in triplicate along with a triplicate of the ARM-1 waste glass reference material [5] and a duplicate of blanks.

\section{MICROSCOPY RESULTS}

A typical backscattered electron (BSE) micrograph of the first ceramic waste form produced from radioactive electrorefiner salt is shown in Figure 1 . The microstructure of the waste form generally consists of sodalite and glass regions, $50-150 \mu \mathrm{m}$ in size. Glass sometimes penetrates into the sodalite regions, though on a much finer scale. Actinide/rare earth-containing phases and halite are minor phases that tend to be found along grain boundaries. Two fission products, Cs and Sr, were below the detection limit of EDS/WDS so they are probably uniformly distributed throughout the sodalite, glass, or halite phases. This microstructure corresponds well with that of previously studied waste forms, which were loaded with surrogate fission product salt or plutonium [6-7].

Rare earths, actinides and yttrium form separate phases in the waste form and often are closely associated with one another. The composition of these phases varies but uranium is predominant throughout. This is unsurprising since the uranium content is at least four times greater than the content of plutonium, rare earths, or yttrium. Due to their small size, the chemical form of these elements could not be determined by SEM/EDS. Previous studies on surrogate fission product- and actinide-doped waste forms suggest that plutonium and rare earths form silicates as well as mixed oxides [7]. However, TEM/ED results on the electrorefiner-saltloaded waste forms show that the uranium, plutonium, and rare earths are predominantly solid solutions of mixed oxides. The plutonium and rare earths may have formed silicates in these other studies because of higher concentrations of plutonium and rare earths in the waste forms. 
Figure 2 is a typical bright field image of the CWF obtained by TEM, where examples of phases are marked. The four phases observed in the sample are as follows: (1) mixed oxide $(\mathrm{Pu}, \mathrm{U}) \mathrm{O}_{2-\mathrm{x}}$ with fluorite structure confirmed by $\mathrm{ED},(2)$ sodalite, (3) glass and (4) halite $(\mathrm{NaCl})$. Occasionally rare earths were detected with the mixed oxide phase as well.

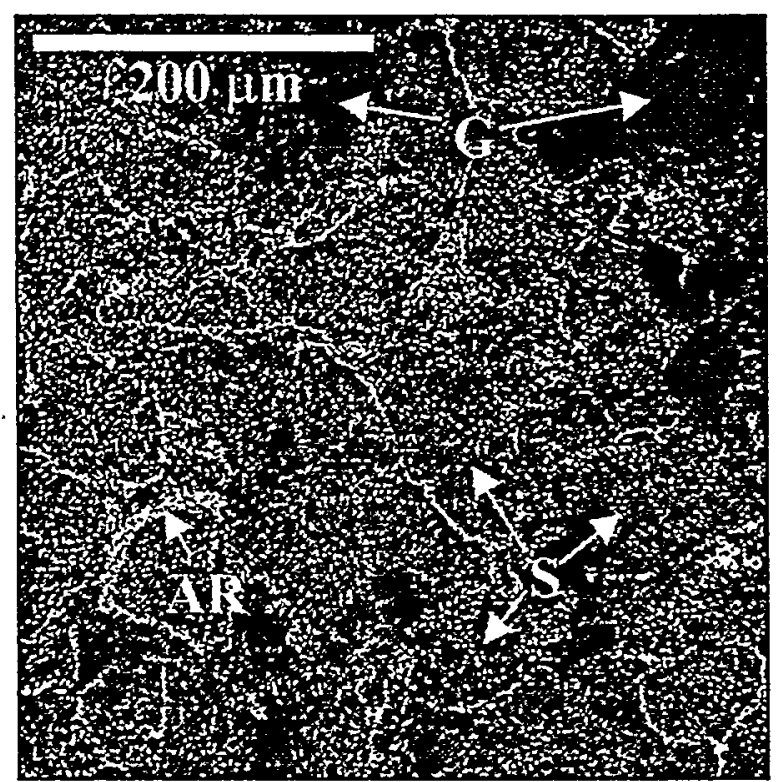

Figure 1. Typical Micrograph of the First CWF Produced with Radioactive Electrorefiner Salt. The CWF generally consists of glass (G) and sodalite (S) granules that are 50-150 $\mu \mathrm{m}$ across. The high contrast inclusions containing various amounts of actinides and rare earths (AR) tend to concentrate along the sodalite grain boundaries.

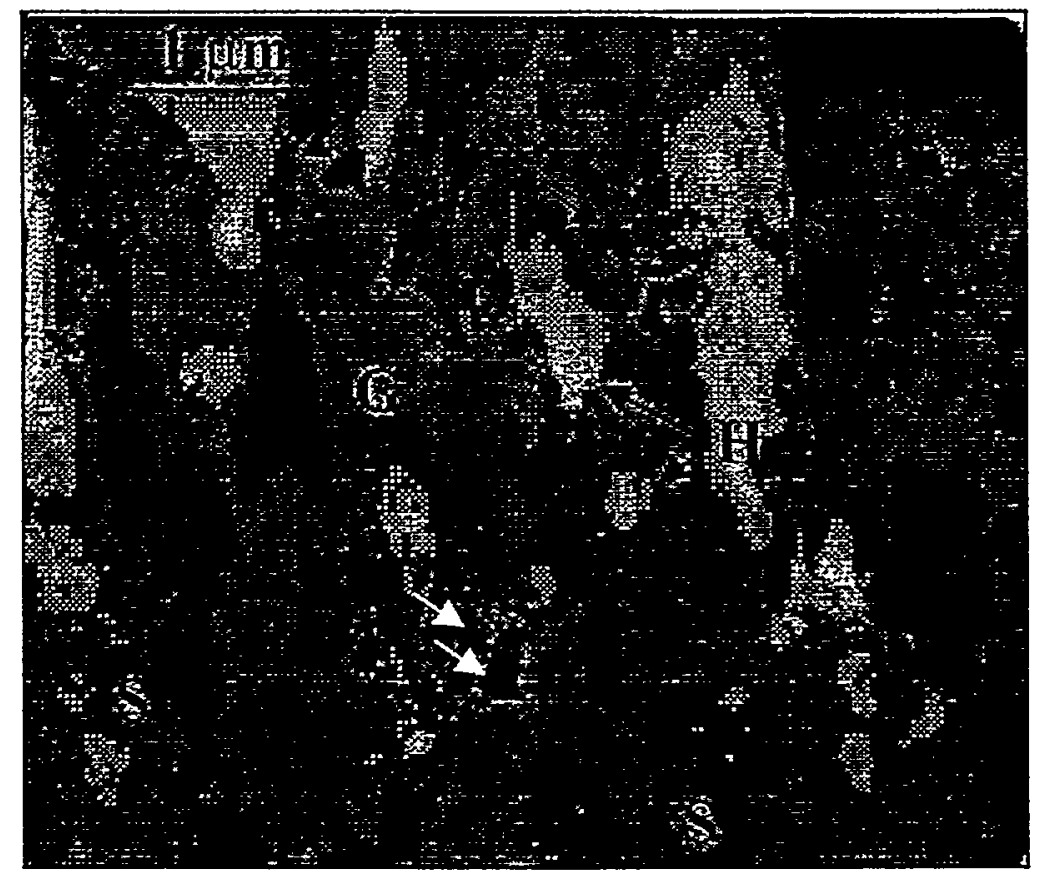

Figure 2. Bright Field Image of the Ceramic Waste Form. The principal phases found by TEM are sodalite $(\mathrm{S})$, glass $(\mathrm{G})$, mixed oxides containing varying amounts of $\mathrm{U}, \mathrm{Pu}$, and rare earths, and spherical halite crystals $(\mathrm{H})$. Unmarked arrows are larger mixed oxide particles. 
The microstructure determined by TEM for the 100-driver salt-loaded CWF was typical of many CWF samples. As was the case with other examinations of the CWF [7], the microstructure of the radioactive salt-loaded CWF is dominated by large regions of glass and sodalite. The halite phase is present as spherical inclusions within the glass, often near the glass/sodalite phase boundary. The actinide-bearing mixed oxide phase is primarily present as fine unfaceted crystals approximately $20 \mathrm{~nm}$ in diameter. In addition to these very fine crystals, a few larger mixed oxide crystals are also present, interspersed within regions containing the smaller grains. The mixed oxide crystals are situated within the glass phase, or occasionally sandwiched between two sodalite regions. The actinide contents of the glass and sodalite phases were near detection limits for EDS. This, plus the existence of a separate actinide-based phase in the CWF, in spite of the actinides being a relatively minor component of the salt, is indicative of a negligible quantity of actinide in either the glass or sodalite phases.

\section{PCT RESULTS}

The results for selected elements of the PCT are given in Table II. In the table, the CWF is also compared with a glass similar to the Defense Waste Processing Facility (DWPF) glass [8] and the Environmental Assessment (EA) glass [5]. As can be seen from Table II, the normalized mass loss for elements in the radioactive CWF is comparable to the DWPF glass and is much smaller than the EA glass.

Comparison of the NML of $\mathrm{Al}$ and Si suggests that the dissolution rates of sodalite and glass are approximately equal. The $\mathrm{Al}$ to $\mathrm{Si}$ ratio in sodalite is approximately equal to one. Consequently, if the glass and sodalite have the same dissolution rate, the normalized releases of $\mathrm{Al}$ and Si should be equal. This comparison, however, does not consider secondary phases that may form and precipitate so more study is necessary to draw conclusions on dissolution rates.

Finally, the mixed oxide phase appears to be very durable. This is clear from the lower NML of actinides, rare earths, and yttrium. The release of $\mathrm{Pu}$ is also lower than that from DWPF glass, given in Table II.

Table II. Normalized Mass Loss for Selected Elements in the 7-Day PCT. Units are in $\mathrm{g} / \mathrm{m}^{2}$.

\begin{tabular}{|c|c|c|c|c|}
\hline \multirow[t]{2}{*}{ Element } & \multirow{2}{*}{$\begin{array}{l}\text { Radioactive } \\
\mathrm{CWF}^{\dagger}\end{array}$} & \multicolumn{2}{|c|}{ DWPF glass [8] } & \multirow{2}{*}{$\begin{array}{l}\text { EA glass } \\
\text { [5] }\end{array}$} \\
\hline & & 200R & $165 / 42$ & \\
\hline $\mathrm{Li}$ & 0.71 & 0.485 & 0.275 & 5.0 \\
\hline $\mathrm{Na}$ & 0.26 & 0.495 & 0.18 & 6.9 \\
\hline $\mathrm{K}$ & 0.14. & 0.285 & & \\
\hline Cs & 0.22 & 0.10 & 0.060 & \\
\hline $\mathrm{Ba}$ & 0.058 & & & \\
\hline $\mathrm{Sr}$ & 0.052 & & 0.0095 & \\
\hline $\mathrm{Si}$ & 0.068 & 0.225 & 0.165 & 4.3 \\
\hline $\mathrm{Al}$ & 0.082 & 0.15 & 0.16 & \\
\hline B & 0.71 & 0.55 & 0.205 & 8.3 \\
\hline $\mathrm{Cl}$ & 2.18 & & & \\
\hline $\mathrm{Y}$ & 0.020 & & & \\
\hline $\mathrm{Ce}$ & 0.018 & & & \\
\hline $\mathrm{Nd}$ & 0.0077 & & & \\
\hline $\mathrm{Pu}$ & 0.013 & $0.049^{\ddagger}$ & $0.065^{\ddagger}$ & \\
\hline $\mathrm{U}$ & 0.010 & & & \\
\hline
\end{tabular}

${ }^{\dagger}$ Errors at two sigma for concentrations used to calculate values are $5 \%$ for $\mathrm{Al}, \mathrm{Li}, \mathrm{K}, \mathrm{Na}$, and $\mathrm{Si}$ and $10 \%$ for all others. ${ }^{\ddagger}$ This value pertains to an alpha emitters, primarily $\mathrm{Pu}-238$ and $\mathrm{Cm}-244$. 


\section{SUMMARY}

The microstructure of the radioactive CWF is very similar to the surrogate and $\mathrm{U} / \mathrm{Pu}$ doped CWFs studied previously. It consists of large sodalite and glass regions with actinide/rare earth/yttrium-containing phases and halite decorating the boundaries between these regions. The uranium, plutonium, yttrium and rare earth fission products are observed in a mixed oxide phase. On a finer scale, this phase tends to be displaced into the glassy regions near the sodalite/glass region boundaries. Cesium and strontium were not observed, but they may be uniformly distributed in the waste form.

Based on the 7-day PCT results, the durability of the radioactive CWF is comparable to the DWPF glass and is much better than the reference EA glass. More durability testing is planned for similar waste forms in other hot isostatically pressed canisters of the waste form material and will be presented at a later date.

\section{ACKNOWLEDGEMENTS}

This work was supported by the U.S. Department of Energy, Nuclear Energy Research and Development Program, under contract no. W-31-109-ENG-38.

\section{REFERENCES}

1. J.P. Ackerman, T.R. Johnson, L.S.H. Chow, E.L. Carls, W.H. Hannum and J.J. Laidler, Prog. Nucl. Energy 31: 141-154 (1997).

2. C. Pereira, M.A. Lewis and J. P. Ackerman, Spent Nuclear Fuel-Treatment Technologies, Reno, NV, 1996.

3. K.M. Goff, R.W. Benedict, K. Bateman, M.A. Lewis, C. Pereira, C.A. Musick, International Topical Meeting on Nuclear and Hazardous Waste Management, Spectrum, Seattle, WA, 2436-2443 (1996).

4. ASTM C1285-94, Standard Test Methods for Determining Chemical Durability of Nuclear Waste Glasses: The Product Consistency Test (PCT), Annual Book of ASTM Standards, (American Society for Testing and Materials, Philadelphia, 1995), pp. 797-814.

5. C. M. Jantzen, N. E. Bibler, D. C. Beam, C. L. Crawford, and M. A. Pickett, Westinghouse Savannah River Co. report WSRC-TR-92-346, revision 1 (1993).

6. S.M. Frank, K.J. Bateman, T. DiSanto, S.G. Johnson, T.L. Moschetti, M.H. Noy, and T.P. O'Holleran in Phase Transformations and Systems Driven Far from Equilibrium, edited by E. Ma, P. Bellon, M. Atzmon, and R. Trivedi (Mat. Res. Soc. Symp. Proc. 481, Warrendale, PA 1998), pp. 351-356.

7. T.L. Moschetti, T.P. O'Holleran, S.M. Frank, S.G. Johnson, D.W. Esh, and K.M. Goff, in Environmental and Waste Management Technologies in the Ceramic and Nuclear Industries $V$, edited by $\mathrm{G}$. T. Chandler and X. Feng (Ceramic Transactions 107, tentative publication date: April 2000); W.S. Sinkler, T.P. O’Holleran,.S.M. Frank, T.L. Moschetti, S.G. Johnson, D.W. Esh, K.M. Goff, ibid.

8. N. E. Bibler and J. K. Bates in Scientific Basis for Nuclear Waste Management XIII, edited by V. Oversby and P. Brown (Mat. Res. Soc. Symp. Proc. 176, Pittsburgh, PA 1990), pp. 327-338. 